\title{
Study on the Practice of "PAD Class" Teaching Mode in English Teaching of Medical Colleges
}

\author{
Yan Li, Xiaoqing Wen, Xianjiu Liao* \\ Youjiang Medical University for Nationalities, Baise, China \\ Email: *lxj2006910@163.com
}

How to cite this paper: Li, Y., Wen, X. Q., \& Liao, X. J. (2021). Study on the Practice of "PAD Class" Teaching Mode in English Teaching of Medical Colleges. Advances in Applied Sociology, 11, 275-280.

https://doi.org/10.4236/aasoci.2021.115024

Received: May 13, 2021

Accepted: May 22, 2021

Published: May 25, 2021

Copyright $\odot 2021$ by author(s) and Scientific Research Publishing Inc. This work is licensed under the Creative Commons Attribution International License (CC BY 4.0).

http://creativecommons.org/licenses/by/4.0/

\begin{abstract}
This study aims to explore whether PAD Class teaching mode can improve the English academic performance of medical students and bring some positive impact on their English learning through random interviews with 8 students. The results show that there is a significant difference in the English academic performance between the experimental class with PAD Class teaching mode and the control class with the traditional teaching mode $(\mathrm{t}=7.12, p$ $<0.001)$; the 8 students in the random interviews said that PAD Class teaching mode plays a positive role for language competence, interactivity between teachers and students or students and students, independent learning ability, and comprehensive problem analysis ability.
\end{abstract}

\section{Keywords}

PAD Class, English Teaching, Self-Learning Ability, Medical Education

\section{Introduction}

The traditional college English class is mostly teaching-based, which refers to that the teachers complete the teaching content in a systematic way following the teaching schedule and plan. This mode not only makes students in a passive learning state, but also exists many drawbacks, such as low learning efficiency, lack of fulfillment and independent thinking, poor independent learning ability, and dullness of classroom (Du \& Zhang, 2016). So what kind of English class can arouse the study enthusiasm of students?

On the basis of cognitive psychology, Professor Zhang Xuexin from the Department of Psychology of Fudan University proposes an original PAD Class teaching mode, and divides PAD Class into three parts: presentation, assimilation and discussion, which greatly improves the situation of contemporary col- 
lege English teaching. The class time is divided into two sections in PAD Class, half of which is given to the teachers for presentation and the other half to the students for discussion. The two-section intervals are one week, which is used by students for assimilation (Zhang, 2014). In general, complete learning is divided into presentation, assimilation and discussion in PAD Class, all of which are interlinked and indispensable.

\section{Study Design}

\subsection{Study Objects}

Class 3 of nursing profession enrolled in 2019 and 2020 of our school were selected as the study objects in this study, which were respectively control class and experimental class. The traditional teaching mode is given in the control class, while PAD Class mode in experimental class. The two classes can be compared with no difference in teacher, teaching materials and schedule, gender balance, age, and English foundation.

\subsection{Study Problems}

This study is designed to explore two issues: one is whether PAD Class teaching mode can improve the English academic performance of students, and the other is whether this mode can bring a positive impact on their English learning.

\section{Study Method}

\subsection{Quantitative Study}

For the first study question, the traditional teaching mode is given in the control class, while PAD Class mode in experimental class. All the students take the final examination unified by the college English section after four months of traditional teaching and experimental teaching. Then SPSS 22.0 is adopted in independent-samples $\mathrm{T}$ test on the final grades of the experimental class and the control class to analyze whether there is a significant difference between the two groups of data.

\subsection{Qualitative Study}

The author randomly select 8 students ( 4 males and 4 females) in the experimental class for interviews focusing on the recognition and attitude of the students towards PAD Class teaching mode. For example, do you like PAD Class? What is your favorite part of PAD Class teaching mode? Which part is more conducive to English learning? What are the unique advantages of PAD Class? Do you want to continue to use PAD Class teaching mode? The interview lasts about 8 - 10 minutes for each student recording with a voice recorder. After the interview, the author converts the recording into text by hand. During the collation of text, the important information should be extracted to analyze whether PAD Class can bring a positive impact on English learning. 


\subsection{Experimental Process}

The experimental class and the control class are taught by the same English teacher, adopting unified teaching materials of the third edition of New Horizon English Course of Reading and Writing and New Horizon English Course of Listening and Speaking, teaching schedule and examining mode. The traditional teaching mode is given in the control class based on presentation. PAD Class teaching mode is given in the experimental class, which makes the class time into three parts: presentation, assimilation, and discussion.

In the presentation stage, the teacher helps students build knowledge framework, clarify key and difficult points, analyze long sentences, and capture the positive materials in teaching materials in the limited time, to conduct the effective teaching of ideological and political course in time and lead positive life attitudes and values. The professional advantages of teacher can be brought into full play in presentation, laying a solid foundation for further and wide-ranging learning and playing a good demonstration role for students.

Assimilation is one of the highlights of PAD Class teaching mode, helping students to develop good habit and attitude of independent learning. During the one-week interval between assimilation and discussion, students have enough learning space and can freely use the adequate learning resources around them, such as library, Bae, CNKI and various video resources to learn in a favorable, step-by-step and purposeful way. For non-English majors, another important task in assimilation process is to prepare for the oral communication in discussion stage. Students can prepare the relevant expressions in advance through dictionaries, online translation and other tools in case of need.

In the discussion stage, the teaching concept of "student-centered" is brought into full play, allowing students to become the masters of learning to explore and tap the possibility of knowledge. The two parts of discussion and assimilation form a close connection, and their mutual supervision and cooperation can better improve students' learning. The students are split up into groups to discuss with each other in this stage, and the representative from each group should make a concluding statement after the discussion. The teacher organizes the students to discuss and supervises them to actively participate in the discussion as the role of organizer, supervisor and mentoring (Yang, Wang, \& Zhang, 2015), and the students can ask the teacher for help at any time to make the discussion efficient.

\section{Study Results and Discussion}

\subsection{Study Question 1: Can PAD Class Teaching Mode Improve the English Academic Performance of Students?}

At the end of the semester, the students in the control class and the experimental class take the final examination unified by the college English section with conformable types, difficulty and scope of the questions. Then the final grades of the two classes are conducted in independent-samples $T$ test. It can be seen from 
Table 1 that there is a significant difference in the grades of the two classes $(t=$ $7.12, p<0.001)$. The grade of the experimental class $(88.8 \pm 4.51)$ is significantly higher than that of the control class $(78.47 \pm 8.91)$, indicating that PAD Class is an efficient teaching mode, which can help students understand, master and memorize knowledge points to improve their English academic performance, which is consistent with other studies (Li \& Zhang, 2021).

\subsection{Study Question 2: Does PAD Class Teaching Mode Have a Positive Impact on English Learning of Students?}

The 8 students who participated in the interview all held a positive attitude towards PAD Class teaching mode, indicating that this mode played an active role in English learning. Throughout the views of these 8 students, the positive effects of PAD Class teaching mode on English learning are reflected in the following aspects:

First, improve language competence and boost self-confidence in learning. In the interview, the students said that one of their favorite parts is discussion, which provides a good platform for them to speak English. Among them, 7 students coming from rural areas said that they have little opportunity to practice oral English due to the limited family conditions, English learning conditions, and learning resources. PAD Class provides a good opportunity for students to practice oral English with preparation and thinking instead of improvisation and blindness. Some students said that they could only speak one or two sentences of English in the group discussion at the beginning, but the situation gradually improved, which was attributed to the exemplary role of students who spoke good English, and the peer pressure, which was controllable and could be overcome as long as you made good preparation. Therefore, PAD Class can help students improve language competence and boost self-confidence in learning.

Second, activate the classroom atmosphere and promote the interactivity between teachers and students or students and students. It can be learned from the interview that the reason why students are afraid to speak English and keep silent is that there are always one or two words that cannot be expressed, resulting in frustration. However, the assimilation stage in PAD Class allows students enough time for purposeful independent learning, such as understanding the words and sentence patterns they don't know by looking up dictionaries or online translation tools. In the discussion, students can have an entry point to participate, thus activating the classroom atmosphere (Xu, 2021). According to the interview, PAD Class also promotes the communication between teachers and

Table 1. Comparison of english academic performance between control class and experimental class.

\begin{tabular}{cccccc}
\hline Grouping & Number & Mean value & Standard deviation & $t$ & $p$ \\
\hline Control class & 56 & 78.47 & 8.91 & 7.12 & 0.001 \\
Experimental class & 60 & 88.8 & 4.51 & & \\
\hline
\end{tabular}


students. In the assimilation stage, students generate all kinds of thinking and confusion in the process of finding, analyzing and solving problems, which enables students to take the initiative to discuss online and offline with teachers in various ways, thus promoting the mutual communication between teachers and students.

Third, cultivate independent learning ability. In the presentation part of PAD Class teaching mode, the teacher leaves the blank for the elaboration, which can inspire the students well and make them into independent internalization learning with problems. The students interviewed said that the study in the assimilation stage of PAD Class makes their study after class well supervised. Under the pressure of discussion, the students will learn independently like finishing their homework and strive to keep up with others in group discussions. A survey from Wang Xing found that $85 \%$ of the students believe that PAD Class teaching mode can improve their independent learning ability (Wang, 2021). The students in the interview said that developing a good habit of independent learning can help learning greatly, improve the core competitiveness of individuals, and lay a good foundation for lifelong learning.

Fourth, improve the comprehensive problem analysis ability. PAD Class can stimulate students to learn and reach the effect of "learning how to learn". In the assimilation stage, students are not only faced with limited book knowledge, but also a variety of effective books and online learning resources, which provide guarantee for students to analyze problems thoroughly and comprehensively from multiple angles and levels. For the discussion part in PAD Class, students have different perspectives and entry points for analyzing problems due to different feelings and experiences. Sharing among groups can make the analysis of problems more thorough, clear and comprehensive. The comprehensive problem analysis ability students can be sublimated and experienced in practice, which will greatly promote the comprehensive understanding and analysis of problems from multiple levels and angles in the future.

\section{Conclusion}

PAD Class teaching mode keeps pace with the time, which not only gives full play to the role of teachers, but also mobilizes the internal learning motivation of students. It can not only help students better understand and master knowledge, improve English academic performance, but also activate the classroom atmosphere, promote the interactivity between teachers and students or students and students, cultivate independent learning ability and comprehensive problem analysis ability of students, and lay a solid foundation for future lifelong learning.

\section{Fund Program}

2018 Guangxi Vocational Education Teaching Reform Research Project + Research and Practice of PAD Class based on WeChat Platform in Higher Vocational Public English Teaching in Minority Areas + (GXGZJG2018B161). 


\section{Conflicts of Interest}

The authors declare no conflicts of interest regarding the publication of this paper.

\section{References}

Du, Y. F., \& Zhang, X. X. (2016). PAD Class: Practice and Thinking on the Reform of Class Teaching Mode in Universities and Colleges. Continuing Education Study, 2016, 116-118.

Li, M. D., \& Zhang, L. Y. (2021). A Mixed-Method Study of PAD Teaching Mode-Based College English Teaching. Journal of Changchun Normal University, 40, 182-185.

Wang, X. (2021). Study on the Application of PAD Class Mode into Reading Teaching of English Majors. Journal of Heilongjiang Institute of Teacher Development, 40, 135-137.

$\mathrm{Xu}, \mathrm{T}$. T. (2021). A Study on the Application of "PAD Class" Teaching Mode in College English Teaching. China Economist, 2021, 195-196+198.

Yang, S. P., Wang, D. W., \& Zhang, L. J. (2015). The Teaching Mode of PAD Class and Its Role Analysis between Teachers and Students. Journal of Liaoning Normal University (Social Science Edition), 38, 653-658.

Zhang, X. X. (2014). PAD Class: A New Attempt in University Teaching Reform. Fudan Education Forum, 12, 5-10. 